\title{
DEVELOPMENT OF FUNCTIONAL DIETARY PRODUCT ON THE BASE OF COMPLEX USE OF LOCAL PLANT RAW MATERIAL
}

\author{
M. Silagadze ${ }^{1}$, E. Pruidze ${ }^{2}$, S. Gachechiladze ${ }^{3}$, \\ M. Khurtsidze ${ }^{4}$ G. Pkhakadze ${ }^{5}$ \\ DOI: http://doi.org/10.15350/L_26/8/16
}

\section{Abstract}

For development of dietary product of functional purpose raw material with high nutritional and biological value have been chosen on the base of study of chemical and micronutrient content of local plant raw material - amaranth grains, topinambour tubers and pumpkin. The effect of semi-finished raw material - amaranth flour, mashed topinambour and pumpkin on the parameters of technological process during maturation of dough and quality of wheat bread has been studied. New sort and preparation technology of dietary bread has been developed called "Gift of the nature" offered for prevention of the diseases with iron deficiency. Its nutritional value and caloricity of the product have been calculated.

Keywords: amaranth, topinambour, pumpkin, dietary nutrition, nutritional and energetic value.

Дефицит макро-, микроэлементов и витаминов в продуктах питания, ухудшение экологической среды обитания, геополитические катаклизмы мирового масштаба способствовали развитию алиментарных заболеваний, таких как сахарный диабет, дислипидемия, железодефицитная анемия (ЖДА), которые называют болезнями XXI века. Особое внимание заслуживает железодефицитная анемия, которую в народе называют малокровием. В основном, этому недугу подвержены дети, подростки и люди старше 50 лет. По данным Международной Организации Здравохранения ЖДА наблюдается у четверти населения планеты $[1,5]$. ЖДА-это патологическое состояние организма, которое вызвано снижением гемоглобина и эритроцитов в крови и спровоцировано недостаточностью железа в организме человека.

Основной принцип диеты при ЖДА состоит в создании и сохранении баланса обязательных для организма веществ, что обеспечивается увели-

${ }^{1}$ Maria Silagadze, full member of the Engineering Academy of Georgia, doctor of technical sciences, professor of Akaki Tsereteli University, Kutaisi, Georgia.

2Eliza Pruidze, candidate of technical sciences, associated professor of Akaki Tsereteli University, Kutaisi, Georgia.

${ }^{3}$ Sofio Gachechiladze, Master of Biology, PHD student of Akaki Tsereteli University, Kutaisi, Georgia.

${ }^{4}$ Manana Khurtsidze, PHD student of Akaki Tsereteli University, Kutaisi, Georgia.

${ }^{5}$ Giorgi Pkhakadze, 12-th class student of Georgian- American School Progress, Kutaisi, Georgia. 
чением приёма полноценных белков, количества сахара-фруктозы, витаминов С и $\mathrm{B}_{12}$, железосодержащих продуктов, а также ограничением жиров и кальцийсодержащих молочных продуктов. Следует учитивать, что некоторые продукты стимулируют всасывание железа, а некоторые наоборот мешают этому процессу. Положительное влияние оказывает высокобелковое растительное сырьё с железом, фруктозой, витаминами С и В12. Негативное влияние на процесс оказывают отруби, молоко и молочные продукты, крепкий чай и кофе (их фенольные соединения), очень жирная пища. Диета при ЖДА предусматривает применение низкокалорийной пищи, это 130 г белка, до 90 г жира, 350 г углеводов, от 7 до 18 мг \% железа (это средняя суточная норма).

Цель работы состояла в подборе регионального пищевого растительного сырья с высоким содержанием белка, железа, минеральных веществ, витаминов и проектировании диетического продукта на их основе, для профилактики ЖДА.

В качестве сырья (функционалных ингредиентов) для конструирования диетического хлеба, взамен части пшеничной муки, из огромного количества растительных ресурсов региона мы выбрали плоды следующих растений - амаранта, топинамбура и тыквы, которые содержат те необходимые вещества, которые представляют основу диетического продукта для профилактики ЖДА, в частности - растительнй белок, железо, фруктозу, витамин С и витаминно-минеральный комплекс.

Амарант - содержит большое количество полноценного белка, а также сахар, жир, мощный антиоксидант-сквален и что самое главное-железо.

Топинамбур или земляная груша - содержит уникальный углеводный комплекс на основе фруктозы и её полимеров. В основном это инулинединственный природный полисахарид, который на 95\% состоит из фруктозы. Он не усваивается желудочно-кишечным трактом, а распадается частично на отдельные молекулы фруктозы под влиянием желудочного сока. Топинамбур содержит большое количество витамина C, витамины группы В, железо и другие минеральные вещества. Его называют диетическим сырьём XXI века. Он содержит минимальное количество крахмала, от 3-х до 7\%.

Тыква - является прекрасным источником простых углеводов. Содержит пищевые волокна - клетчатку, витамины, минералы, каротин. Особенно богата сахарами, витамином С, железом.

Объектами исследования служили мука из зерна амаранта, пюре из плодов тыквы и клубней топинамбура, изготовленные нами в лабораторных условиях.

Образцы исследуемого сырья были урожая 2015 года, выращенные в фермерских хозяйствах Цхалтубского муниципалитета. В работе также использовали пшеничную муку высшего сорта, прессованные дрожжи, соль, растительное (амарантовое) масло. Эксперименты проводились в химической, биохимической и технологической лабораториях департамента технологии пищевых продуктов Государственного университета Акакия 
Церетели (г. Кутаиси, Грузия).

Содержание общего азота, с пересчётом на общий белок, определяли по методу Къелдаля; определение содержания жира проводили методом экстракции по Сокслету; массовой доли крахмала-поляриметрическим методом Эверса, содержание сахара-методом Бертрана. Реологические характеристики муки и физические свойства теста исследовали на фаринографе $[2,3]$.

Органолептический и физико-химический анализ полуфабрикатов и хлеба проводили по стандартным методикам, принятым в хлебопекарной промышленности. Энергетическую ценность продукта рассчитывали с помощью коэфициентов Рубнера [2].

С точки зрения применения в диетотерапии больных ЖДА мы должны были получить продукт, в котором максимально должны быть сбалансированы следующие ингредиенты - растительный белок, железо, витамин С, кальций, моносахариды, в частности фруктоза, пищевые волокна (клетчатка) и органические кислоты. При подборе сырья объязательным условиям, помимо оптимального соотношения ингредиентов, была их низкая калорийность. При разработке нового диетического ассортимента хлеба необходимо было предусмотреть, что внесение каждой новой добавки в тесто сопровождается модификацией структуры полуфабриката и в определённый критический момент существенно меняются структурно-механические свойства полуфабрикатов (вязкость, пластичность, эластичность), что в конечном счёте отражается на качестве готового продукта. С этой целью мы апробировали каждое сырье в отдельности, а затем уже изучали их комплексное влияние.

В начале эксперимента мы исследовали содержание основных компонентов, микронутриентный состав и калорийность подобранного сырья (таблица 1.)

При подготовке сырья к проведению анализов в лабораторных условиях из зерна амаранта готовили муку с выходом 60\%. Из клубней топинамбура и мякоти тыквы готовили пюре. При проведении пробных лабораторных выпечек пшеничное тесто готовили безопарным способом. Контролем служил пшеничный хлеб из муки высшего сорта, который готовили по рецептуре - мука пшеничная в/с-100кг, дрожжи прессованные2кг, соль-1,3кг, вода - по расчёту, с учётом влажности сырья и готовых изделий. Все компоненты рассчитывали в \%-х от массы муки в тесте.

После замеса созревание (брожение) теста проводили в термостате при температуре $28-30^{\circ} \mathrm{C}$. Формование тестовых зоготовок осуществляли вручную, а расстойку проводили в расстойном шкафу в атмосфере пара, при температуре $35-40^{\circ} \mathrm{C}$. Выпечку изделий проводили в лабораторной конвекционной печи с увлажнением вначале выпечки. 
Таблица 1

Содержание макро-, микронутриентов и витаминов в сырье (мг\%)

\begin{tabular}{|c|c|c|c|c|}
\hline \multirow[b]{2}{*}{ Компоненты } & \multicolumn{4}{|c|}{ Количество компонентов (мг\%) } \\
\hline & $\begin{array}{c}\text { Контроль-пшеничная } \\
\text { мука в/с }\end{array}$ & $\begin{array}{l}\text { Мука ама- } \\
\text { ранта }\end{array}$ & $\begin{array}{c}\text { Мякоть топинам- } \\
\text { бура }\end{array}$ & $\begin{array}{r}\text { Мякоть } \\
\text { тыквы }\end{array}$ \\
\hline \multicolumn{5}{|c|}{ Макроэлементы } \\
\hline Кальций & 18 & 159 & 78,4 & 25 \\
\hline Магний & 16 & 248 & 31,7 & 14 \\
\hline Натрий & 3 & 4 & 172,0 & 4 \\
\hline Калий & 122 & 508 & 1382,0 & 204 \\
\hline Фосфор & 86 & 557 & - & 25 \\
\hline \multicolumn{5}{|c|}{ Микроэлементы } \\
\hline Железо & 1,2 & 7,61 & 10,4 & 0,4 \\
\hline Цинк & 0,7 & 2,87 & - & 0,24 \\
\hline Медь,мкг & 100,0 & 525 & - & 180,0 \\
\hline Марганец & 0,57 & 3,33 & 44,0 & 0,04 \\
\hline Селен,мкг & 6,0 & 18,7 & - & - \\
\hline \multicolumn{5}{|c|}{ Витамины } \\
\hline $\mathrm{B}_{1}$ [Тиамин] & 0,17 & 0,116 & 0,9 & 0,05 \\
\hline $\mathrm{B}_{2}$ [Рибофлавин] & 0,04 & 0,2 & 6,4 & 0,06 \\
\hline $\begin{array}{c}\mathrm{B}_{5} \text { [Пантотеиновая кис- } \\
\text { лота] }\end{array}$ & 0,3 & 1,457 & 0,7 & 0,4 \\
\hline $\mathrm{B}_{6}$ [пиридоксин] & 0,17 & 0,591 & 0,22 & 0,1 \\
\hline $\begin{array}{c}\text { B9[Фолиевая кислота], }_{\text {мкг }} \\
\end{array}$ & 27,1 & 82 & - & 14 \\
\hline $\begin{array}{c}\text { C[Аскорбиновая кис- } \\
\text { лота] }\end{array}$ & - & 4,2 & 98 & 8 \\
\hline $\begin{array}{c}\text { PP [Никотиновая кис- } \\
\text { лота] }\end{array}$ & 1,2 & 0,923 & - & 0,5 \\
\hline
\end{tabular}

На следующем этапе работы уточнялись оптимальные дозировки муки из амаранта, пюре из топинамбура и тыквы, которые составили: для амаранта $8-10 \%$, для топинамбура $10-15 \%$ и для тыквы $12-15 \%$ от массы муки в тесте. В таблице 2 отражены результаты влияния оптимальных дозировок указанных добавок на показатели качества пшеничного хлеба при внесении в тесто добавок в оптимальных дозировках (раздельно), а также при комплексном их использовании. В ходе эксериментов были уточнены параметры технологического процесса приготовления диетического хлеба.

Было установлено, что применяемые добавки оптимизируют процессы брожения теста за счёт собственных сахаров тыквы и амаранта, а также за счёт фруктозы, которая накапливается в тесте в процессе брожения в результате гидролиз инулина под действием органических кислот. Период созревания теста сокращается в среднем на 30-60 минут. Установлено, что предлагаемые добавки в оптимальных дозировках оказывают значительное влияние на комплекс процессов, протекающих во время созревания теста, в частности ускоряется процесс накопления кислотности, увеличивается газообразование на 8-12\%, бродильная активность и подъёмная сила дрожжей в 1,5-2,0 раза по сравнению с контролем; меняются структурно-механические свойства теста, в частности увеличивается водопоглотительная способность и водоудерживаемость теста, повышается 
эластичность на 7-39\%, а разжижжаемость уменьшается на 18-52\%. Опытные образцы хлеба не только не уступают контрольному, но и превосходят их по ряду показателей (данные таблицы 2).

Таблица 2

Влияние выбранного сырья на показатели качества пшеничного хлеба

\begin{tabular}{|c|c|c|c|c|c|}
\hline \multirow[b]{2}{*}{$\begin{array}{c}\text { Показатели } \\
\text { качества хлеба }\end{array}$} & \multirow{2}{*}{$\begin{array}{c}\text { Контроль- } \\
\text { пшеничны } \\
\text { хлеб из муки } \\
\text { в/с }\end{array}$} & \multicolumn{4}{|c|}{$\begin{array}{c}\text { Хлеб с различными добавками } \\
\text { (в оптимальных дозировках), } \\
\text { в \%-х от массы муки в тесте }\end{array}$} \\
\hline & & $\begin{array}{c}\text { Мякоть } \\
\text { тыквы- } \\
15 \%\end{array}$ & $\begin{array}{c}\text { Амаранто- } \\
\text { вая мука- } \\
10 \%\end{array}$ & $\begin{array}{c}\text { Мякоть } \\
\text { топинамбура- } \\
15 \%\end{array}$ & $\begin{array}{c}\text { Добавка } \\
\text { комплексно, } \\
\text { в оптимальных } \\
\text { дозировках } \\
\end{array}$ \\
\hline Влажность,\% & 41,2 & 52,2 & 41,8 & 42,2 & 42,4 \\
\hline $\begin{array}{c}\text { Титруемая кислотность, } \\
{ }^{\circ} \mathrm{H}\end{array}$ & 2,4 & 2,2 & 3,4 & 3,6 & 3,2 \\
\hline Пористость,\% & 72 & 78 & 69 & 75 & 74 \\
\hline $\begin{array}{c}\text { Удельный } \\
\text { объем,мл/100г }\end{array}$ & 330 & 380 & 310 & 360 & 350 \\
\hline $\begin{array}{c}\text { Формоустойчивость } \\
\text { Н/Д }\end{array}$ & 0,36 & 0,53 & 0,35 & 0,52 & 0,50 \\
\hline $\begin{array}{c}\text { Органолептическая } \\
\text { оценка,в баллах }\end{array}$ & 78 & 80 & 82 & 82 & 80 \\
\hline
\end{tabular}

В завершение исследований мы расчитали пищевую ценность и калорийность диетического продукта. Для этого определяли количество белка, жира и углеводов в контрольном и опытном образцах хлеба. Показано, что калорийность хлеба снизилась на 20\%, с 241,8 ккал в контроле до 189,1 ккал в диетическом хлебе (табл. 3).

Таблица 3

Пищевая и энергетическая ценность пшеничного хлеба

\begin{tabular}{|c|c|c|}
\hline Содержание основных компонентов & Контроль & $\begin{array}{c}\text { Опытный образец } \\
\text { (диетический хлеб) }\end{array}$ \\
\hline Белки & 7,4 & 6,3 \\
\hline Жиры & 0,8 & 1,1 \\
\hline Углеводы & 53,0 & 38,6 \\
\hline Энергетическая ценность, ккал & 241,8 & 189,5 \\
\hline
\end{tabular}

На основе проведённых исследований разработан новый сорт диетического хлеба „Дары природы“ и технология его приготовления. Рецептура предлагаемого ассортимента представлена в таблице 4.

Таблица 4

Рецептура диетического хлеба

\begin{tabular}{|c|c|}
\hline Наименование сырья & Количество сырья, кг(на 100 кг муки в тесте) \\
\hline Пшеничная мука в/с & 60,0 \\
\hline Амарантовая мука & 10,0 \\
\hline Мякоть тыквы & 15,0 \\
\hline Мякоть топинамбура & 15,0 \\
\hline Прессованные дрожжи & 2,0 \\
\hline Соль & 1,5 \\
\hline Амарантовое масло & 2,0 \\
\hline
\end{tabular}

Итого 105,5 


\section{Выводы}

Проведено исследование, направленное на разработку диетического хлеба высокой биологической ценности на основе комплексного использования регионального сырья-муки амаранта, пюре из плодов тыквы и топинамбура с целью последующего применеия диетического продукта в диетотерапии железодефицитной анемии:

Результаты изучения общего химического и микронутриентного состава, технологических свойств и энергетической ценности муки амаранта, пюре из тыквы и топинамбура свидетельствуют об их высокой пищевой и биологической ценности. Полуфабрикаты тыквы и топинамбура являются низкокалорийными продуктами (22 кКал и 61 кКал соответственно).

Установлено влияние дозировок указанных добавок на параметры приготовления теста и показатели качества готовых изделий. Определены рациональные дозировки, которые составили: для амарантовой муки 8$10 \%$, для пюре из топинамбура 10-15\% и для пюре из тыквы 12-15\% к массе пшеничной муки в тесте.

Установлено, что предлагаемые добавки ускоряют процесс накапливания кислотности - увеличивается газообразование на 8-12\%, бродильная активность и подъёмная сила дрожжей в 1,5-2,0 раза по сравнению с контролем; увеличивается водопоглотительная способность и водоудерживаемость теста, повышается эластичность на 7-39\%, а разжижжаемость уменьшается на $18-52 \%$.

Разработан новый сорт диетического хлеба с фирменным названием „Дары природы“ и технология его производства.

Калорийность диетического продукта составила 189,1 кКал против 241,8 кКал для традиционного пшеничного хлеба из муки высшего сорта.

\section{References}

[1] Комилова Д. Обогащение хлебобулочных изделий белком / Д.Комилова, Г.Дубцов // Ж. Хлебопекарное производство. №10. 2010. с.25-26.

[2] Корячкина С.Я., Лабутина Н.В. Контроль качества сырья, полуфабрикатов и хлебобулочных изделий. М.-Дели.-2012.-496 с.

[3] Пучкова, Л.И. Лабораторный практикум по технологии хлебопекарного производства: учеб. пособие для ВУЗов /Л.И. Пучкова. 4-е изд. перераб. и доп. СПб: ГИОРД, 2004. -259c.

[4] Силагадзе М., Пруидзе Э., Хуцидзе Ц. Биохимические и технолгические исследования зерновой культуры амарант, произрастающей в субтропической зоне Грузии // Ж.Субтропические культуры. №1-2. Озургети-Анасеули.2005. с.253254.

[5] Тутельян В. Питание и здоровье // Ж.Пищевая промышленность. №5. 2004. с. 67. 